\title{
METHODOLOGY FOR REDUCING RISK OF UNDERPERFORMANCE OF PERSONNEL FUNCTIONS
}

\author{
Elena Klochkova ${ }^{1}$, Konstantin Evdokimov ${ }^{2}$, Yuri Klochkov ${ }^{1}$, Vyacheslav Samorukov ${ }^{2}$ \\ ${ }^{1}$ Peter the Great Saint-Petersburg Polytechnic University, Russia; ${ }^{2}$ Saint-Petersburg State Agrarian \\ University, Russia \\ samarienne@ya.ru,eknmanager@mail.ru,y.kloch@gmail.com, luckyterenteva@yandex.ru
}

\begin{abstract}
Personnel training is a significant part of a management system of any organization; for instance, ISO 9001 standard discusses it in detail. However, it should be defined, who and what is to be trained. Training should increase the personnel qualification level, thus increasing the probability of successful task performance. If we determine the probability of not performing a task for each task, for which a staff member is responsible, we will be able to design a professional development program effectively. It should also be taken into account, in which period a specific staff member should be trained. The paper suggests a method for designing a professional development program that considers such factors as probability of successful task performance, suitable training periods and offers of professional development programs at a specific labor market.
\end{abstract}

Keywords: risk, personnel, quality.

\section{Introduction}

Personnel qualification plays an important role in achieving a higher quality level of operation and production in an organization, therefore solution of quality assurance problems is closely related to personnel. Modern market situation of total competition makes clear that not money and material resources are the main capital of a company, but people making them. Moreover, people are not merely a resource, but the most valuable asset of an organization; they differ from other types of resources, because human resources are a self-increasing value. Like any other resource, the human resource requires all the necessary and ongoing investment, as its quality directly affects the quality of products, the speed of execution of all necessary works and the overall level of costs $[1 ; 2]$.

Staff training and development becomes a permanent item of expenditures and a core responsibility of management. Therefore, the improvement of procedures for production and technical activities is achieved by improving the skills of the staff, developing its knowledge and skills. The purpose of the present paper is development of a methodology for reducing the risk of non-fulfilment of functions (work) by personnel.

Risk assessment methods in human resources management are usually based on surveys among employees and the assessment of the employees' satisfaction. These methods suggest selecting several companies, organizing a survey and analyzing the results of the survey, what serves as a basis for developing measures to improve the working environment. Such surveys allow to identify risks stated by employees; however, they may be useless in detecting conflicts between functions. In other words, an employee can describe the problems related to his/her working functions but he/she is unable to identify problems related to the whole system of functions [3].

The present paper approaches the problem under study differently. The general procedure includes the following steps. At first, we assess the functions performed by a specific employee, what allows to identify functions, which can be performed by several employees and functions performed by only one employee. Based on this analysis, we assessed the risk of (not) performing a function. If only one employee can perform the function, a company is at risk of not performing it; therefore, this risk should be reduced.

\section{Materials and methods}

As the object of the research the Operation and Technical Department of the enterprise "VolgoProdMontazh LLC" was chosen. At present, "VolgoProMontazh" has its own production line, hoisting machines and motor vehicles, welding equipment, hand tools and technological equipment [4; 5]. The Operation and Technical Department was chosen for the present analysis, since it performs a variety of tasks: pre-production preparation, organization of production activities from the stage of making outsource agreements to the stage of the product acceptance and commissioning. 
The Operation and Technical Department supervises the activities of building and construction and departments and construction sites, monitors compliance with technological regulations, identifies the reasons for their violation, and interacts with all participants of the technical process to optimize production costs and to ensure meeting the deadlines.

The operational quality of the Operation and Technical Department depends on the personnel. One of the main problems is the low speed of task execution. To clarify the causes of the problem, we have to assess the following parameters:

- functions of the employees in a specific project;

- risk;

- complexity of the functions performed;

- quality level of employee's performance;

- employee's qualification level;

- quality of employee's work;

- level of risk.

Interpretation of the assessment parameters and scale of assessment

\begin{tabular}{|c|c|c|c|}
\hline № & Parameter & Explanation & $\begin{array}{l}\text { Indicators characterizing the } \\
\text { parameter, scale of assessment }\end{array}$ \\
\hline 1 & 2 & 3 & 4 \\
\hline 1 & Functions & $\begin{array}{l}\text { Functions (not) performed by a } \\
\text { particular employee }\end{array}$ & $\begin{array}{l}\text { Estimated using the method of expert } \\
\text { assessments }\end{array}$ \\
\hline 2 & Risk & $\begin{array}{l}\text { Number of employees able to } \\
\text { perform specific functions }\end{array}$ & $\begin{array}{l}\text { Estimated according to the following } \\
\text { scale: } \\
\text { 1-2 employees - red zone; } \\
\text { 3-4 employees - yellow zone; } \\
\text { 5-6 employees - green zone }\end{array}$ \\
\hline 3 & $\begin{array}{l}\text { Complexity of } \\
\text { the functions } \\
\text { performed }\end{array}$ & Difficulty of task performance. & $\begin{array}{l}\text { Assessed on a } 5 \text {-point scale ( } 1 \text {-point - } \\
\text { minimum complexity, } 5 \text { points - } \\
\text { maximum). }\end{array}$ \\
\hline 4 & $\begin{array}{l}\text { Quality level } \\
\text { of employee's } \\
\text { performance }\end{array}$ & $\begin{array}{l}\text { Quality of the tasks performed; } \\
\text { Qualitative assessment and } \\
\text { problems }\end{array}$ & $\begin{array}{l}\text { Estimated on a 3-point scale: } \\
\text { - If there are problems }-3 \text { points }-60 \% \\
\text { performance; } \\
\text { - If problems are rare }-2 \text { points }-80 \% \\
\text { performance; } \\
\text { - If problems do not occur - } 1 \text { point - } \\
100 \% \text { execution }\end{array}$ \\
\hline 5 & $\begin{array}{l}\text { Employee's } \\
\text { qualification } \\
\text { level }\end{array}$ & $\begin{array}{l}\text { Sufficient set of specific skills and } \\
\text { knowledge of an employee } \\
\text { necessary to carry out work of a } \\
\text { certain complexity }\end{array}$ & $\begin{array}{l}\text { Complexity of the work performed by } \\
\text { this employee, and the overall } \\
\text { complexity of all the work in general. }\end{array}$ \\
\hline 6 & $\begin{array}{l}\text { Quality of the } \\
\text { employee's } \\
\text { work }\end{array}$ & $\begin{array}{l}\text { Aggregated quality level of an } \\
\text { employee in various functions. } \\
\text { Overall employee's performance }\end{array}$ & $\begin{array}{l}\text { Level of quality of a specific employee; } \\
\text { the highest possible level of quality of } \\
\text { all works in general }\end{array}$ \\
\hline 7 & Risk level & $\begin{array}{l}\text { Possibility of unfavourable events } \\
\text { in production and technology }\end{array}$ & $\begin{array}{l}\text { Sum of the red and yellow zones } \\
\text { multiplied by the corresponding weights } \\
\text { and the maximum risk }\end{array}$ \\
\hline
\end{tabular}

The main functional responsibilities of the Operation and Technical Department defined by job descriptions include:

1. Pre-operating phase.

- Obtaining working documentation; verification of project documentation for compliance with the project scope of work and specification of materials, completeness of the package of documents. Making comments and suggestions, working with general contractors-customers. 
- Timely issuance of working documentation for construction sites;

- Scheduling the production of works in conjunction with the sites;

- Development of production projects;

- Development ofoperating process charts;

- Compilation or verification of requisitions for materials and equipment;

- Making manufacturing orders;

- Obtaining work permits, incl. opening of warrants, orders and coordination of work;

- Timely issuance of projects for the production of works, work logs, etc., the necessary documentation in accordance with regulatory requirements and requirements of customers;

2. Technical supervision of construction works:

- Current control of the amount of work performed, of its compliance with the approved design estimates, working drawings, construction standards, safety standards, requirements for rational work organization;

- Current quality control of the work performed, for their compliance with the approved design and estimate documentation, work drawings, construction standards, safety standardsand requirements for rational work organization;

- Monitoring of compliance with the work schedule;

- Monitoring of compliance with the solutions developed in the work project;

- Control of timely delivery of works to the general contractor-customer and controlling authorities;

- Development of measures for construction cost reduction and coordination of design solutions changes with the customer and design organizations;

- Solution of ongoing matters during the production;

- Delivery of objects to the customer:

- Preparation, completion, execution and transfer of the finished executive documentation to the general contractor-customer;

- Control of timely delivery of works to the general contractor-customer (signing of acts) [6; 7].

\section{Risk assessment methodology}

In this section we propose a methodology for personnel evaluation. To begin with, we construct Table 2, where the employees of the Operation and Technical Department are represented in rows and the functions are represented in columns. For convenience, we indicate the employees through alphabetic symbols as follows: Velikanov V.P. - P1;Klyushkina O.A. - P2; Nurhametova A.N. P3; Novikov K.V. - P4;Galimullin I.R. - P5;Nesterov SG - P6.

In the columns, the functions are denoted by the numbers. The main purpose of the table is to define the tasks performed by employees (functions) and to identify the risk zones. Let us estimate what functions (indicated in the columns of the table) a specific person (indicated in a row of Table 2) can perform. To do this, we mark the intersection of the row (Employees) and the column of the corresponding function with dashed lines.

To assess the risk, we use a tool called Traffic Light. The risk of non-fulfillment of the project on time is related to the number of employees that can perform this type of work (functions). If this number of people are 1-2, the risk is high, i.e. it is a red zone. For example, if a P5 employee fell ill or for some other reason did not come to work, then all projects would immediately stuck at work 4, which this employee was supposed to perform. If a function can be performed by 3-4 workers, the risk level is average, i.e. it is a yellow zone; if a function can be performed by 5-6 employees, the risk is low, i.e. it is a green zone.

In this table, the lowest row indicates the risk zones for each work (function): red, yellow and green, designated as R, Y, G, respectively.We can see that the works under No. 4, 5, 8, 12, 13, 15, 18 are in the red risk zones (R), works under No. 1, 2, 3, 6, 7, 9, 10, 11, 14 are in the yellow zones (Y), and works under the numbers 16,17 are in the green zones $(\mathrm{G})$.

Thus, quantitatively there are 7 red regions $(\mathrm{R}), 9$ yellow areas $(\mathrm{Y})$ and 2 green $(\mathrm{G})$.In percentage terms, the red zones $(\mathrm{R})$ are $39 \%$, the yellow zones $(\mathrm{Y})$ are $50 \%$, the green $(\mathrm{G})$ zones are $11 \%$. 
Interpretation of the assessment parameters and scale of assessment

\begin{tabular}{|c|c|c|c|c|c|c|c|c|c|c|c|c|c|c|c|c|c|c|}
\hline \multirow{2}{*}{ Employees } & \multicolumn{18}{|c|}{ Functions (work) } \\
\hline & 1 & 2 & 3 & 4 & 5 & 6 & 7 & 8 & 9 & 10 & 11 & 12 & 13 & 14 & 15 & 16 & 17 & 18 \\
\hline \multicolumn{19}{|l|}{ P1 } \\
\hline & & & & & & & & & & & & & & & & & & \\
\hline & 1 & 2 & 3 & 4 & 5 & 6 & 7 & 8 & 9 & 10 & 11 & 12 & 13 & 14 & 15 & 16 & 17 & 18 \\
\hline \multicolumn{19}{|l|}{$\mathrm{P} 2$} \\
\hline & & & & & & & & & & & & & & & & & & \\
\hline & 1 & 2 & 3 & 4 & 5 & 6 & 7 & 8 & 9 & 10 & 11 & 12 & 13 & 14 & 15 & 16 & 17 & 18 \\
\hline \multirow{2}{*}{\multicolumn{19}{|c|}{ P3 }} \\
\hline & & & & & & & & & & & & & & & & & & \\
\hline & 1 & 2 & 3 & 4 & 5 & 6 & 7 & 8 & 9 & 10 & 11 & 12 & 13 & 14 & 15 & 16 & 17 & 18 \\
\hline \multirow{2}{*}{\multicolumn{19}{|c|}{$\mathrm{P} 4$}} \\
\hline & & & & & & & & & & & & & & & & & & \\
\hline & 1 & 2 & 3 & 4 & 5 & 6 & 7 & 8 & 9 & 10 & 11 & 12 & 13 & 14 & 15 & 16 & 17 & 18 \\
\hline \multirow{2}{*}{\multicolumn{19}{|c|}{ P5 }} \\
\hline & & & & & & & & & & & & & & & & & & \\
\hline & 1 & 2 & 3 & 4 & 5 & 6 & 7 & 8 & 9 & 10 & 11 & 12 & 13 & 14 & 15 & 16 & 17 & 18 \\
\hline P6 & & & & & & & & & & & & & & & & & & \\
\hline Risk & $\mathrm{Y}$ & $\mathrm{Y}$ & $\bar{Y}$ & $\mathrm{R}$ & $\mathrm{R}$ & $\mathrm{Y}$ & $\mathrm{Y}$ & $\mathrm{R}$ & $\mathrm{Y}$ & $\mathrm{Y}$ & $\mathrm{Y}$ & $\mathrm{R}$ & $\mathrm{R}$ & $\mathrm{Y}$ & $\mathrm{R}$ & G & G & $\mathrm{R}$ \\
\hline
\end{tabular}

Estimation of the complexity of work.

The complexity of each function performed is determined based on the analysis and generalization of the data using the method of expert assessments. A simple evaluation was used, in which the complexity of functions was assessed by the head of the service, i.e. Head of the Operation and Technical Department. [6] This method does not require any significant costs, but its drawback is that this assessment is highly subjective.

Estimates are made on a 5-point scale (1 point - minimum complexity, 5 points - maximum difficulty). The results are shown in Table 3. It consists of two rows that contain information about the complexity of each function. Each cell contains an estimate (from 1 to 5) for each corresponding function (1-18), what reflects the level of complexity of performing this work (function).

Table3

Assessment of the complexity of work (functions)

\begin{tabular}{|c|c|c|c|c|c|c|c|c|c|c|c|c|c|c|c|c|c|c|}
\hline Work number & 1 & 2 & 3 & 4 & 5 & 6 & 7 & 8 & 9 & 10 & 11 & 12 & 13 & 14 & 15 & 16 & 17 & 18 \\
\hline Complexity & 4 & 2 & 4 & 5 & 3 & 2 & 4 & 3 & 2 & 2 & 5 & 3 & 4 & 2 & 5 & 3 & 4 & 4 \\
\hline
\end{tabular}

Assessment of the performance level of works.

The quality of the whole project is a sum of the quality of each function performed. Therefore, using the method of expert assessments, the level of quality of works performed is assessed as a whole for projects and employees, thus providing an integral assessment for overall work quality using a 3point scale $[4 ; 8]$. The evaluation is based on the following considerations:

- if there are problems -3 points $-60 \%$ performance;

- if problems are rare -2 points $-80 \%$ performance;

- if problems do not occur - 1 point $-100 \%$ execution.

The results are shown in Table 4 consisting of two rows, which indicate the quality of performance of each work (1-18). In a cell, for each corresponding function (1-18), an assessment (from 1 to 3 ) is made, which reflects the quality level of the performance of this work (function). 
Assessment of the quality level of works (functions)

Table4

\begin{tabular}{|c|c|c|c|c|c|c|c|c|c|c|c|c|c|c|c|c|c|c|}
\hline Work number & 1 & 2 & 3 & 4 & 5 & 6 & 7 & 8 & 9 & 10 & 11 & 12 & 13 & 14 & 15 & 16 & 17 & 18 \\
\hline Quality & 3 & 1 & 2 & 2 & 1 & 1 & 1 & 1 & 2 & 2 & 2 & 2 & 1 & 3 & 2 & 2 & 1 & 2 \\
\hline
\end{tabular}

We consider the quality of a project as a function of risk and performance assessment.

Quality of the project $=f(R, B)$,

where $R$-risk;

$B$ - quality of work.

Let us construct the final table (Table 5), where we present information about the functions performed by the personnel. The central part of the table consists of columns that correspond to the functions of the Operation and Technical Department, and the rows indicate employees of the Department. The head of the Table shows the information about the complexity (weight coefficients) of functions (works). In cells, dashed lines mark the functions performed.

The right part of the table consists of an assessment of the skill level indicator and the level of work quality of each employee that were obtained above using the calculation. The lower part of the table contains the results of the risk assessment and the analysis of the level of quality of performance of functions (works) as a whole for projects. This method of assessing the work of the Operation and Technical Department makes possible to obtain double assessment for the employees and double assessment of the functions.

Table5

Results of the study

\begin{tabular}{|c|c|c|c|c|c|c|c|c|c|c|c|c|c|c|c|c|c|c|c|c|}
\hline \multirow{4}{*}{ 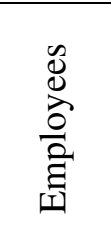 } & \multicolumn{18}{|c|}{ Complexity (weight coefficient) } & \multirow{4}{*}{ 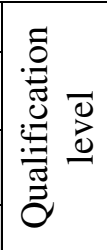 } & \multirow{4}{*}{ 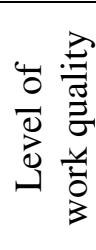 } \\
\hline & 4 & 2 & 4 & 5 & 3 & 2 & 4 & 3 & 2 & 2 & 5 & 3 & 4 & 2 & 5 & 3 & 4 & 4 & & \\
\hline & \multicolumn{18}{|c|}{ (Functions) work } & & \\
\hline & 1 & 2 & 3 & 4 & 5 & 6 & 7 & 8 & 9 & 10 & 11 & 12 & 13 & \begin{tabular}{|l|l|}
14 \\
\end{tabular} & 15 & 16 & 17 & 18 & & \\
\hline \multirow[t]{2}{*}{ P1 } & & & & & & & & & & & & & & & & & & & 0.72 & 0.83 \\
\hline & 1 & 2 & 3 & 4 & 5 & 6 & 7 & 8 & 9 & 10 & 11 & 12 & 13 & 14 & 15 & 16 & 17 & 18 & & \\
\hline \multirow[t]{2}{*}{$\mathrm{P} 2$} & & & & & & & & & & & & & & & & & & & 0.69 & 0.85 \\
\hline & 1 & 2 & 3 & 4 & 5 & 6 & 7 & 8 & 9 & 10 & 11 & 12 & 13 & \begin{tabular}{|l|}
14 \\
\end{tabular} & 15 & 16 & 17 & 18 & & \\
\hline \multirow[t]{2}{*}{$\mathrm{P} 3$} & & & & & & & & & & & & & & & & & & & 0.26 & 0.93 \\
\hline & 1 & 2 & 3 & 4 & 5 & 6 & 7 & 8 & 9 & 10 & 11 & 12 & 13 & 14 & 15 & 16 & 17 & 18 & & \\
\hline \multirow[t]{2}{*}{$\mathrm{P} 4$} & & & & & & & & & & & & & & & & & & & 0.34 & 0.91 \\
\hline & 1 & 2 & 3 & 4 & 5 & 6 & 7 & 8 & 9 & 10 & 11 & 12 & 13 & 14 & 15 & 16 & 17 & 18 & & \\
\hline \multirow[t]{2}{*}{ P5 } & & & & & & & & & & & & & & & & & & & 0.46 & 0.83 \\
\hline & 1 & 2 & 3 & 4 & 5 & 6 & 7 & 8 & 9 & 10 & 11 & 12 & 13 & 14 & 15 & 16 & 17 & 18 & & \\
\hline P6 & & & & & & & & & & & & & & & & & & & 0.34 & 0.86 \\
\hline Risk & $\mathrm{Y}$ & Y & $\mathrm{Y}$ & $\mathrm{R}$ & $\mathrm{R}$ & $\mathrm{Y}$ & $\mathrm{Y}$ & $\mathrm{R}$ & $\mathrm{Y}$ & $\mathrm{Y}$ & $\mathrm{Y}$ & $\mathrm{R}$ & $\mathrm{R}$ & $\mathrm{Y}$ & $\mathrm{R}$ & $\mathrm{G}$ & G & $\mathrm{R}$ & & \\
\hline $\begin{array}{l}\text { Quality } \\
\text { control }\end{array}$ & 0.6 & 1 & 0.8 & 0.8 & 1 & 1 & 1 & 1 & 0.8 & 0.8 & 0.8 & 0.8 & 1 & 0.6 & 0.8 & 0.8 & 1 & 0.8 & & \\
\hline
\end{tabular}

Calculating the level of risk.

The level of risk is the ratio of the sum of red and yellow zones multiplied by the corresponding weight coefficients to the maximum risk.

$$
L r=\frac{10 \times k+6 \times m}{10 \times n},
$$

where $k$-number of red zones;

$m$ - number of yellow zones;

$n$ - total number of zones $(\mathrm{R}+\mathrm{Y}+\mathrm{G})$; 
10 - coefficient of the red zone $(\mathrm{R})$;

6 - coefficient of the yellow zone (Y);

$10 n$ - maximum risk.

$$
L r=\frac{10 \times 7+6 \times 9}{10 \times 18}=\frac{124}{180}=0.69
$$

Thus, $L r=0.69$ is the amount of the current risk.

Based on the analysis, we can conclude that the department works in an extremely risky mode; the loss of any of the employees leads to a catastrophe and work stoppage at the Department. In order to avoid this and to improve the efficiency, it is recommended to recruit new employees, or to make the current ones more diversified by introducing professional training. The aim is to transform all red zones into yellow ones, and all yellow ones into green ones, thereby reducing the risk.

\section{Development of recommendations and activities to address the problem under study}

Before proceeding to the training and development of the personnel in the Operation and Technical Department under consideration, it is necessary to develop, organize and systematize the most complete and effective scheme for this training. Its content and direction depend on the specifics of the activities of the unit and the organization as a whole, the level of competence of the personnel and should not be situational in nature, that is, be divorced from the company's development strategy, the general personnel policy and the changing requirements of the industry and the market [9].

The choice of an educational institution for professional development is of great importance, but for the most part even high-quality courses do not bring the desired effect, if the following questions are not answered in the development of a training plan for personnel:

- when and on what days to conduct training;

- which employees need to improve their qualifications;

- what functions the employee should master in the learning process.

The correct establishment of the order of sending the staff to the courses of professional development and developing a timetable for training is an important task. To this end, it is necessary to analyse the state of the department's operating mode in the case, when one of the employees goes on training to prevent all risk zones from becoming red.

By sending an employee to training, in his absence we get 11 red (R) and 7 yellow (Y) risk zones (Table 6).

Table 6

Status of the department's work mode when sent employee

\begin{tabular}{|l|l|l|l|l|l|l|l|l|l|l|l|l|l|l|l|l|l|l|}
\hline & 1 & 2 & 3 & 4 & 5 & 6 & 7 & 8 & 9 & 10 & 11 & 12 & 13 & 14 & 15 & 16 & 17 & 18 \\
\hline P1 & R & Y & R & R & R & Y & Y & R & Y & Y & R & R & R & R & R & Y & Y & R \\
\hline P2 & R & Y & Y & R & R & Y & R & R & Y & Y & R & R & R & R & R & Y & Y & R \\
\hline P3 & Y & Y & Y & R & R & Y & R & R & R & Y & Y & R & R & Y & R & G & Y & Y \\
\hline P4 & Y & Y & R & R & R & Y & R & R & R & Y & Y & R & R & Y & R & Y & Y & R \\
\hline P5 & R & Y & R & R & R & Y & Y & R & R & Y & Y & R & R & Y & R & Y & Y & R \\
\hline P6 & Y & Y & Y & R & R & Y & Y & R & Y & Y & R & R & R & R & R & Y & Y & R \\
\hline
\end{tabular}

Having considered all the different options for sending employees, we come to the conclusion that the absence of key employees will lead to disaster and we cannot stop our production and technical system, so we need to either hire a new employee to get rid of red areas, or conduct training on weekends: on Saturdays and Sundays. Moreover, it should take place in a remote or electronic format without interruption from work with the use of innovative teaching technologies, modern information and computer support (webinars, online seminars), as well as in the form of corporate training with the departure of teachers to the enterprise [10].

The next important task is to determine the sequence of the training process and determine the number of employees to be sent to the refresher courses. When solving this problem, the order should begin with the employee, whose training helps fill in most of the red and yellow functions. 
Let us count this number for each employee:

- for worker P1 this number is equal to 5 functions, of which 3 red (R) and 2 yellow (Y);

- for employee P2 this number is equal to 6 functions, of which 3 red (R) and 3 yellow (Y);

- for employee P3 this number is 11 functions, of which 7 are red (R) and 4 are yellow (Y);

- for worker P4 this number is equal to 11 functions, of which 7 are red (R) and 4 are yellow (Y);

- for employee P5 this number is equal to 9 functions, of which 3 are red (R) and 6 are yellow (Y);

- for worker P6 this number is equal to 11 functions, of which 6 are red (R) and 5 are yellow $(\mathrm{Y})$.

Having determined for each of them a specific value for red and yellow functions, we conclude that the first course is for employee P3 or P4, since their training will allow to fill in the maximum number of red and yellow risk zones, equal to 11. Training of employee P6 will also allow to close the maximum number of zones, but not so many reds, which are priority, hence it should go after P3, or $\mathrm{P} 4$. Then, in the same way, we form the following procedure for training the remaining employees, namely P5, P2, P1.

To solve the problem of determining the functions and jobs for which the staff should be trained, information was used on the functions that are not fulfilled by each employee. Based on this, tables were compiled for all employees taking into account the sequence of training, what gives an opportunity to get an answer to the question: which of the programs will enable to acquire the necessary skills. This will allow choosing the best programs for different employees for certain functions. In addition, senior management will be able to draw conclusions about the method to improve the qualification of an employee so that (s)he is able to perform more work.

Table 7

Selection of the optimal training program for employee P3

\begin{tabular}{|c|c|c|c|c|c|c|c|c|c|c|c|c|c|}
\hline \multirow{2}{*}{ Program } & \multicolumn{10}{|c|}{ Functions not performed by an employee } & Total studied \\
\cline { 2 - 10 } & 1 & 3 & 4 & 5 & 8 & 11 & 12 & 13 & 14 & 15 & 16 & 18 & functions \\
\hline 1 & + & & & + & + & + & & + & + & + & + & & 8 \\
\hline 2 & + & + & + & + & + & & + & & + & & & & 7 \\
\hline 3 & & + & + & + & & + & + & + & & + & & & 7 \\
\hline 4 & + & + & + & + & + & & & + & & & + & & 7 \\
\hline 5 & + & & & & + & & & & & & & & 2 \\
\hline 6 & + & & & & + & & & & & & & + & 3 \\
\hline 7 & & & & & & & & + & + & & & + & 3 \\
\hline 8 & & + & + & + & & + & + & + & + & & & + & 8 \\
\hline 9 & + & & & & & + & + & + & + & & + & + & 7 \\
\hline 10 & & & & + & & + & + & + & & + & + & & 6 \\
\hline 11 & & + & & & & & + & & & & & & 2 \\
\hline 12 & + & & & & + & + & & + & + & & & + & 6 \\
\hline 13 & & + & + & + & & & + & + & & & & & 5 \\
\hline & $\mathrm{Y}$ & $\mathrm{Y}$ & $\mathrm{R}$ & $\mathrm{R}$ & $\mathrm{R}$ & $\mathrm{Y}$ & $\mathrm{R}$ & $\mathrm{R}$ & $\mathrm{Y}$ & $\mathrm{R}$ & $\mathrm{G}$ & $\mathrm{R}$ & \\
\hline
\end{tabular}

Legend: + - function included in the program;

$\mathrm{R}$ - red risk zone;

$\mathrm{Y}$ - yellow risk zone;

$\mathrm{G}-$ green risk zone.

\section{Results and discussion}

The analysis of a number of advanced training courses, using the tables presented below, makes it possible to identify the optimal training program for different employees in terms of the number of functions studied.

Thus, for the P3 employee, the programs most closely related to his needs for upgrading his qualifications are programs No. 1 and No. 8. However, if you take into account the number of red and 
yellow zones that are closed, program No. 3, which allows you to get rid of 5 red functions and 2 yellow ones, is eliminated, but to master fewer jobs.

For other workers it is done in the same way. It is also proposed to train workers with minimal work experience directly in the organization using a passive method of teaching - lecturing. It is used in the case, when the functions cannot be independently mastered in working conditions or without work interruption. Its essence consists in creating training groups of less experienced employees under the guidance of experienced and competent employees of the department [11].

First of all, the roles of teachers and students (listeners) are determined, and a list of the types of work to be trained is selected. Lecturers are selected from reliable employees and should meet the following requirements: high qualifications, engagement in identical work, consideration of the needs of trained workers, a positive attitude towards their work and department. Another important factor is the ability of the teacher to support interest and inclusion of students in the learning process, and to reduce their resistance and critical attitude to the material studied.

Specialists responsible for this type of training should be provided with all the necessary equipment, financial resources, material resources and conditions required for its implementation, as well as salaries for the lectures.

The theoretical course is taught by one of the well-trained specialists using visual and computer methods of studying, for example, presentations and ends with the passing of an examination to another one. Lectures are held on weekends, their duration is set by senior management [12].

In addition, the training process can include seminars that will enable you to repeat a certain amount of the material you have passed, to ensure its better memorability and connection with practice. Furthermore, the personal qualities necessary for fruitful activity in the organization, such as responsibility, ability to work in a team, the ability to communicate with business, a good opinion about one's work, the desire to constantly improve, should be formed and educated among employees.

In our case, such training is structured as follows. Workers V.P. Velikanov. and O. Klyushkina, who are the most experienced, possessing a considerably higher level of qualification than the others, can act as teachers and conduct training for 10 job functions out of 18. Nurhametova AN, Novikov KV, Galimullin IR and Nesterov SG are trained.

Velikanov V.P. reads theoretical lectures or conducts seminars on the studied functions (works) No, 1, 8, 11, 15, 17, and Klyushkina OA organizes the exam. In relation to the functions No. 6, 10, 14, 16, 18 teachers swap the roles. As a result, the red and yellow risk zones are filled in for these functions.

The ultimate goal of training in this methodology is the training of an employee with a high professional level that meets the specific requirements of this department, its goals and requests. However, these goals can be achieved only with the support and participation of senior management, who is supposed to monitor the progress of training, provide the required conditions, and to analyze and evaluate the effectiveness of the completed type of training upon completion of the training together with the teachers.

As a result, the group form enables the staff to master profound skills meeting modern requirements, to obtain the necessary theoretical and methodological knowledge, to get used to their duties, to establish relations with colleagues and to contribute to the activities of the department. The advantage of this method is due to low time and money costs.

\section{Conclusions}

Improving the procedures of production and technical activities is related to the work of personnel and is carried out by improving its skills. An organization should be interested in the continuous growth of the professional skills of its employees, as well as the development of their personal qualities, because training of employees is the most important factor in reducing staff turnover and increasing the efficiency of work, competitiveness and successful development of the enterprise in the changing market economy.

Based on the analysis carried out to improve production and technical activities of an organization, it was concluded that the Operation and Technical Department in our case study works 
in a risky mode. The analysis identified the presence of risk zones, as well as the problems of inconsistency of the staff's knowledge and skills and job duties performed, and the possibility of providing the personnel with training. The following recommendations and activities were developed to address the problem:

1. Parameters have been identified that include indicators, for which it is necessary to evaluate the personnel of the production and technical department, characterizing both general moments equivalent to all employees of the company, and the specifics of work and behavior for a particular position.

2. In fact, a new methodology for assessing and attesting the personnel of the production and technical department on several parameters was developed on the basis of the method of expert assessments, which is necessary to assess the actual state of the operating mode of the production and technical department, and allows to determine the further development of production and technical activities. and contributes to reducing the risk of non-fulfillment functions.

3. A general approach to the training of personnel and its elements is proposed, which involves studying, updating and deepening job duties, as well as skills, knowledge and skills aimed at fulfilling certain functional tasks and achieving stable changes in professional activity.

4. The training and development methodology has been organized according to several schemes. The organization offers advanced training courses, so that the staff can master the necessary functions. And also the introduction of internal passive methods of teaching - lecturing, providing training for workers with minimal experience on the job and creating personnel with a high level of professional knowledge, skills and abilities that meet the specific requirements of this unit, its goals and requests.

5. Of the set of additional educational programs, providers of courses and institutions of professional development, the most adapted to the needs of certain employees of the department are selected accurately taking into account the different level of their preparedness.

6. The algorithm of the educational process is determined and the training schedule is drawn up.

7. A list of those functions and jobs, to which the staff should be trained, which is necessary for them to increase competence and efficiency of work, is established.

8. A new calculation of the level of staff qualifications and the level of risk has been carried out to assess the effectiveness of the training conducted.

\section{Acknowledgements}

The paper is based on research carried out with the financial support of the grant of the Russian Science Foundation (Project No 14-38-00009). Peter the Great St. Petersburg Polytechnic University.

\section{References}

[1] Klochkov Yu. S., Lepehin A.I., Vasilega D. S., Vasilega N. A., Nonieva K. Z., Vasilyeva S. E. Professional orientation of students. Strategic Partnership of Universities and Enterprises of HiTech Branches (Science. Education. Innovations) (SPUE) 2017 IEEE VI Forum on, 2017, pp. 165-167. DOI: 10.1109/IVForum.2017.8246081

[2] Klochkov Yu. S., Didenko N.I., Makov K.M., Zapivahin I.O., Ostapenko M.S., Volgina A.D. Employment and professional adaptation of specialists. Strategic Partnership of Universities and Enterprises of Hi-Tech Branches (Science. Education. Innovations) (SPUE) 2017 IEEE VI Forum on, 2017, pp. 162-164. DOI: 10.1109/IVForum.2017.8246080

[3] Portoghese I., Galletta M., Coppola R.c., Finco G., Campagna M. Burnout and workload among health care workers: The moderating role of job control. Safety and Health at Work, 5(3), 2014, pp. 152-157.

[4] Gazizulina A. Yu., Krasulina O. Yu., Borremans A. D., Tveryakov A. M., Ostapenko M. S., Vasilyeva, S. E. Reducing the risk of staff failures. Strategic Partnership of Universities and Enterprises of Hi-Tech Branches (Science. Education. Innovations) (SPUE) 2017 IEEE VI Forum on, 2017, pp. 199-202. DOI: 10.1109/IVForum.2017.8246091

[5] Pimenova A., Kuzmina S., Zavialov K., Ushakova E. Personnel controlling system principles and structural goals of the industrial companies. IOP Conference Series: Earth and Environmental Science, vol. 90, issue 1, article number 012005, 2017, DOI: 10.1088/1755-1315/90/1/012005 
[6] Golovin N.M., Skripnuk D.F., Klochkova E.S., Alasas B.M., Chernyshov M. O., Kireev, V.V. Evaluation of interaction between Russian universities and foreign universities. Strategic Partnership of Universities and Enterprises of Hi-Tech Branches (Science. Education. Innovations) (SPUE) 2017 IEEE VI Forum on, 2017, pp. 134-136. DOI: 10.1109/IVForum.2017.8246072

[7] Klochkova E.S., Alasas B. M., Esedulaev R.R., Tveryakov A. M., Vasily'ev D. V., Krayneva R. K. Assessment of the quality of higher professional education on the basis of professional and social accreditation. Strategic Partnership of Universities and Enterprises of HiTech Branches (Science. Education. Innovations) (SPUE) 2017 IEEE VI Forum on, 2017, pp. 137-140.DOI: 10.1109/IVForum.2017.8246073

[8] Gazizulina A. Yu., Mirolyubova O. V., Konakhina N. A., Kikkas K. N., Grigorieva A. A., Danilova, S. Yu. Problems of forming requirements to training of specialists for industrial and economic complex. Strategic Partnership of Universities and Enterprises of Hi-Tech Branches (Science. Education. Innovations) (SPUE) 2017 IEEE VI Forum on, 2017, pp. 196-198. DOI: 10.1109/IVForum.2017.8246090

[9] Zaychenko I. M., Kalinina O. V., Gutman S. S. Labor resources of the far north territories: Problems and prospects. Proceedings of the 28th International Business Information Management Association Conference - Vision 2020: Innovation Management, Development Sustainability, and Competitive Economic Growth, 2016, pp. 758-767.

[10] Davliatova M.A., Starodubtsev Y.I. Higher educational institutions functioning assessment and quality management under the conditions of globalization. Strategic Partnership of Universities and Enterprises of Hi-Tech Branches (Science. Education. Innovations) (SPUE) 2017 IEEE VI Forum on, 2017, pp. 215-217. DOI: 10.1109/IVForum.2017.8246096

[11] Krasyuk I. A., Bakharev V. V., Kozlova N. A., Mirzoeva, D. D. Staffing in the sphere of trade: The main issues and prospects of solution. Strategic Partnership of Universities and Enterprises of Hi-Tech Branches (Science. Education. Innovations) (SPUE) 2017 IEEE VI Forum on, 2017, pp. 48-50. DOI: 10.1109/IVForum.2017.8246047

[12] Kuladzhi T. V., Babkin A. V., Murtazaev S-A. Yu. Enhancing personnel training for the industrial and economic complex in the conditions of the digital economy. Strategic Partnership of Universities and Enterprises of Hi-Tech Branches (Science. Education. Innovations) (SPUE) 2017 IEEE VI Forum on, 2017, pp. 67-70. DOI: 10.1109/IVForum.2017.8246053 